\title{
TRABALHO COLETIVO, SUJEITO E PRÁTICA DA CONVERSAÇÃO: uma contribuição a partir da perspectiva psicanalítica à educação especial
}

\author{
Libéria Rodrigues Neves \\ Universidade Federal de Minas Gerais - UFMG \\ Mônica Maria Farid Rahme \\ Universidade Federal de Minas Gerais - UFMG
}

\begin{abstract}
Resumo
O desafio da construção de um trabalho coletivo que viabilize a inclusão escolar de estudantes da Educação Especial tem sido constantemente citado na literatura educacional. São muitos e diversos os fatores que inviabilizam a parceria entre os professores no cotidiano escolar. Considerando este contexto, o presente artigo analisa a temática do trabalho colaborativo previsto nas políticas públicas, focalizando dados colhidos durante a realização da prática da conversação em duas escolas da rede pública (municipal e estadual) localizadas na cidade de Belo Horizonte (Minas Gerais). Os encontros de orientação psicanalítica, fortemente marcados pela circulação da palavra dos professores, indicaram o quanto a abertura de espaços de fala na escola possibilita uma maior elaboração do sujeito em relação à sua prática e uma interlocução com os pares. Desse modo, propõe-se pensar o trabalho colaborativo para além da parceria objetiva entre professores, mas incluindo aquilo que escapa às normativas - a dimensão da subjetividade -, para a contínua produção de saber, no coletivo, diante da diversidade que constitui o universo escolar.
\end{abstract}

Palavras-chave: Trabalho coletivo, Educação Especial, Atendimento Educacional Especializado, Conversação, Psicanálise.

\begin{abstract}
The challenge of building a collective work that enables the school inclusion of students in Special Education has been constantly mentioned in the educational literature. There are many and diverse factors that preclude the partnership between teachers in the school routine. Considering this context, this article analyzes the theme of collaborative work foreseen in public policies, focusing on data collected during the use of conversation in two public schools (elementary and secondary) located in the city of Belo Horizonte (Minas Gerais). The holding of psychoanalytic orientation meetings strongly marked by the circulation of the teachers' utterances, indicated how much the opening spaces where speaking can take place at school allows for greater elaboration of the subject to his practice and a dialogue with peers. Therefore, we propose thinking about collaborative work beyond the objective partnership between teachers, but including what escapes the norms - the dimension of subjectivity -, for the continuous knowledge production collectively, in the face of the diversity that constitutes the school universe.
\end{abstract}

Keywords: Collective work, Special Education, Specialized Educational Service, Conversation, Psychoanalysis. 


\section{Introdução}

O processo de construção de uma educação mais igualitária para os estudantes que compõem o público da Educação Especial evidencia a conexão presente entre as mentalidades sociais, a constituição de percursos educativos e a estruturação de práticas pedagógicas que consigam lidar com o fato de que a diversidade dos tempos e modos de aprendizagem dos sujeitos é inexorável aos processos de escolarização. Tal premissa, cada vez mais discutida atualmente, não minimiza, entretanto, as marcas históricas que recobrem os inúmeros mecanismos de segregação registrados ao longo dos anos e que ainda hoje desafiam a trajetória dos estudantes que apresentam diferenças físicas, sensoriais, intelectuais, motoras, mentais e/ou psíquicas.

A ampliação do direito à educação no Brasil para as crianças e jovens em idade escolar, em especial para aqueles que apresentam particularidades, acompanha um movimento similar ao que tem ocorrido nos últimos anos em vários outros países, no sentido de ampliar o acesso à educação escolar em ambientes cada vez mais abertos a uma convivência comum e menos afeita à perspectiva do especial, naquilo que ele possa significar em termos de separação (PLAISANCE, 2019). Para tanto, um conjunto de documentos legais orienta, desde a promulgação da Constituição Federal de 1988, a implementação de diversos mecanismos que passam a estruturar os sistemas de ensino do país, definindo sua organização e modos de funcionamento. Um desses dispositivos é o atendimento educacional especializado (AEE), que nos últimos anos configurou-se por meio da oferta das salas de recursos multifuncionais (SRM), como delineado na Política Nacional de Educação Especial na perspectiva da Educação Inclusiva (PNEEPEI), de 2008.

Como ressaltam Kassar e Rebelo (2011), a expressão atendimento educacional especializado aparece citada em um dos últimos documentos produzidos em 1986, pelo extinto Centro Nacional de Educação Especial - CENESP, significando, neste, um meio para desenvolver as potencialidades do aluno com deficiência e viabilizar a integração. Na Constituição Federal de 1988, onde vem explícita a priorização da educação escolar dos alunos com deficiência na escola regular, registra-se a referência ao atendimento educacional especializado (BRASIL, 1988), endossado pela Política Nacional de Educação Especial de 1994, embora sem maiores aprofundamentos. As autoras assinalam que a referência ao atendimento educacional especializado será retomada de modo mais significativo a partir dos anos 2000, em documentos como a Resolução CNE/CEB 2001 ${ }^{1}$, que lhe atribui o lugar de agente da Educação Especial na forma de um atendimento diferenciado, e o Parecer CNE/CEB 17/2001. Nos anos seguintes, sua associação às SRM vai se consolidando paulatinamente, assim como sua função de apoio, suplementação, complementação, suporte às necessidades educacionais especiais dos alunos, que deve ser oferecida na escola.

Este percurso, após duas décadas, culminou na promulgação da atual Política PNEEPEI (MEC, 2008), a qual acompanha os avanços nas lutas sociais e na produção do conhecimento, visando constituir programas promotores de uma educação de qualidade para todos os estudantes. A partir de então, tem-se a Educação Especial como uma modalidade de ensino transversal a todos os níveis, etapas e modalidades, a qual realiza o atendimento educacional 
especializado (AEE), por meio de recursos e serviços devidamente orientados, de modo a favorecer o acesso à aprendizagem, ao público da Educação Especial, nas escolas comuns.

Nessa perspectiva, o atendimento educacional especializado (AEE) tem como função (MEC, 2009) identificar, elaborar e organizar recursos pedagógicos e de acessibilidade que eliminem as barreiras para a plena participação dos estudantes, considerando suas necessidades específicas. As atividades desenvolvidas nesse atendimento educacional diferenciam-se daquelas realizadas na sala de aula comum, não sendo substitutivas à escolarização. $\mathrm{O}$ atendimento complementa e/ou suplementa a formação dos estudantes com vistas à autonomia e independência na escola e fora dela. Ao longo de todo o processo de escolarização, esse atendimento deve estar articulado à proposta pedagógica do ensino comum, acompanhado de instrumentos que possibilitem monitoramento e avaliação da oferta realizada nas escolas (da rede pública) e/ou nos centros de atendimento educacional especializados públicos ou conveniados.

O AEE torna-se, portanto, elemento central diante desta perspectiva em que a Educação Especial passa a integrar a proposta pedagógica da escola comum. Entretanto, suas ações para ultrapassar as barreiras que certos conhecimentos, linguagens e recursos representam para os alunos com deficiência podem ser incipientes se desarticuladas do trabalho conjunto, coletivo, em parceria e colaboração, envolvendo professores regentes da sala comum, professores de atendimento educacional especializado e demais atores responsáveis pelos processos de escolarização dos sujeitos com deficiência na escola comum. Diz o texto:

A Educação Especial direciona suas ações para o atendimento às especificidades desses estudantes no processo educacional e, no âmbito de uma atuação mais ampla na escola, orienta a organização de redes de apoio, a formação continuada, a identificação de recursos, serviços e o desenvolvimento de práticas colaborativas. (MEC, 2008)

Nesse sentido, a falta de diálogo entre os profissionais diretamente envolvidos certamente significa um dos grandes fatores que inviabilizam a efetivação do que preconizam a políticas e a legislação. Os motivos para tal desarticulação certamente não são poucos. Podemos citar questões objetivas que perpassam aspectos históricos, econômicos, sociais, organizacionais entre tantos. No entanto, este trabalho pretende um olhar para o que está mais além das questões objetivas. Interessa-nos aqui destacar elementos da dimensão das singularidades, referentes aos sujeitos professores, que escapam às normativas e que só podem ser tratados no um a um.

Para tal, vem apresentar e discutir alguns recortes de uma pesquisa-intervenção de orientação psicanalítica, na abordagem de impasses subjetivos presentes no coletivo de professores, em escolas que localizam dificuldades em realizar um trabalho em conjunto para a inclusão de alunos com deficiência. A pesquisa vem sendo desenvolvida até então a partir de três escolas pertencentes ao sistema de ensino estadual de Minas Gerais (MG) e ao sistema de ensino municipal da capital do estado, Belo Horizonte (BH).

De modo a situar o contexto da pesquisa, faremos inicialmente uma breve abordagem histórica do atendimento educacional especializado, bem como da institucionalização de 
espaços especializados na região, de modo a compreendermos o percurso que antecede a construção dos modelos atuais de atendimento às pessoas com deficiência na escola comum. Nessa retomada histórica, destaca-se o trabalho precursor da psicóloga russa Helena Antipoff (1892-1974), seja na introdução dos saberes psicológicos na jovem capital mineira, seja no movimento de criar instituições de atendimento e associações que agregavam a intelectualidade da época, interessada nas questões relativas à infância pobre, abandonada ou considerada anormal.

Em seguida, serão destacadas as políticas adotadas no estado de MG e na cidade de $\mathrm{BH}$, a partir das diretrizes das secretarias estadual e municipal de educação, no que se refere ao atendimento dos sujeitos da Educação Especial.

Por fim, serão abordados alguns recortes da pesquisa, os quais serão tratados a partir das contribuições da psicanálise à educação, de modo a propor uma discussão acerca daquilo que não se vê incluído nos projetos das políticas públicas - a subjetividade daqueles que podem torná-las efetivas.

\section{Helena Antipoff e os primórdios do atendimento educacional especializado em Minas Gerais}

A história da Educação Especial em Minas Gerais dialoga com a história da educação brasileira, a qual, por sua vez, se constrói a partir de influências dos acontecimentos no mundo ocidental, em especial, das nações que participaram e das que ainda participam no desenvolvimento econômico e cultural do país. Nesse sentido, é possível verificar que o atendimento aos alunos que apresentavam particularidades nos seus modos de aprendizagem, neste estado, foi fortemente marcado pela presença da psicóloga russa Helena Antipoff na região, quem desempenhou papel de grande relevância no estabelecimento das áreas de estudo e pesquisa em psicologia e educação em nosso país a partir de 1929, influenciando diretamente as concepções e métodos de ensino relativos à Educação Especializada.

De acordo com Campos (2002; 2010), antes de chegar a Minas Gerais, Helena Antipoff estagiou no Laboratório de Alfred Binet e Theodore Simon, criado em 1904, e de onde nasceram as pesquisas sobre Testes de Inteligência, que culminaram na criação da primeira escala, conhecida como "Escala Binet-Simon", em 1905. Nesse laboratório, conheceu o psicólogo suíço Édouard Claparède (1873-1940), considerado como um dos grandes nomes da Psicologia da Educação, e quem a convida a fazer parte da primeira turma do recém-criado Instituto Jean-Jacques Rousseau (IJR), um importante centro de estudos em Ciências da Educação, situado em Genebra, na Suíça, onde também foi professora a partir de 1927. O Instituto mantinha a preocupação com os direitos da criança, dialogando com os ideais da Escola Nova, considerando a criança como o centro do processo educativo - quem de fato conduz o processo de aprendizagem - e prezando o respeito às diferenças individuais.

No intuito de contribuir no movimento de renovação das escolas públicas mineiras, em 1929, Helena Antipoff foi convidada pelo governo de MG para assumir as aulas de Psicologia da Educação e Psicologia Experimental da Escola de Aperfeiçoamento de Professores de 
Belo Horizonte, além da criação do primeiro Laboratório de Psicologia. Participou, portanto, na formação de educadores e de psicólogos, na criação de instituições educacionais e, principalmente no projeto de homogeneização das classes escolares, prevista desde 1927 pelo Regulamento do Ensino Primário.

A partir de então, passa a contribuir com o treinamento de professoras para avaliar as crianças, divulgando padrões e métodos para descrever as características psicológicas e psicossociais de alunos das escolas públicas; identificando aqueles que fugiam da normalidade esperada, os quais passaram a ser alvo de interesse dessa psicóloga, educadora e pesquisadora.

Em 1932, foi criada por Helena Antippoff, juntamente com um grupo organizado, a Sociedade Pestalozzi de MG (SPMG), responsável pela criação do Instituto Pestalozzi, com a pretensão de se dedicar aos cuidados, educação e tratamento das crianças classificadas como anormais. Passou a dar auxílio às então criadas classes especiais, as quais já estavam sendo implementadas em países da Europa, a partir do desafio da obrigatoriedade do Ensino Primário. Além dessa função, tal instituição se tornou um importante centro de triagens para as classes especiais, além de oferecer o tratamento e acompanhamento para as crianças que não conseguiam seguir a turma na qual deveriam estar inseridas, buscando-se adaptar os métodos pedagógicos às aptidões da criança. Helena Antipoff desenvolveu ainda exercícios de ortopedia mental, cada qual com o objetivo de treinar funções superiores, como a atenção, a discriminação visual e auditiva, partindo das funções mentais mais básicas; além do uso de atividades como canto, desenho, encadernação, sapataria e jardinagem, entre outras (BORGES; CAMPOS, 2018).

Com um trabalho que partia do ideário da Escola Nova, o Instituto Pestalozzi estabeleceu-se como uma escola especial, no modelo de externato, por meio de um ensino que pretendia o avanço das crianças, embora respeitando-se seus limites. Em salas com menos alunos, professores capacitados, aulas diferenciadas, ensino individualizado, Antipoff acreditava que esse ensino diferenciado poderia promover o desenvolvimento das crianças chamadas anormais.

\section{Os espaços especializados no atendimento de pessoas com deficiências em MG - das APAE's à escola comum}

De acordo com Borges e Campos (2018, p. 74), "entre os anos de 1950 e de 1990, as escolas especiais assumem o protagonismo da educação dos alunos com deficiência”. E paralelamente ao fortalecimento das escolas especiais, as classes especiais continuaram funcionando no estado, mas, aos poucos, seu público foi sendo alterado para crianças sem deficiência e com defasagens de aprendizagem.

No final da década de 1950, Helena Antipoff mobilizou lideranças políticas, profissionais de diversas áreas e a sociedade em geral num movimento organizado em defesa de direitos e de prestação de serviços de qualidade às pessoas com deficiência intelectual e 
deficiência múltipla, e a suas famílias. Propagava a ideia de que somente um movimento social genuíno de pais e amigos teria fôlego e força para influenciar os governos e sociedade.

Cabe destacar, nesse período, a fundação das APAE's (Associação de Pais e Amigos dos Excepcionais) - a primeira, estabelecida no Rio de Janeiro e, a primeira APAE de MG, estabelecida na cidade de São Lourenço, em 1956. Dali o movimento se espalhou para todo o estado, atingindo mais de 400 municípios mineiros. Muitas vezes funcionando como ponte entre escolas comuns e escolas especiais (que passaram a se expandir, não só em Minas, mas em todo o Brasil), atendendo às demandas das primeiras com relação aos diagnósticos e aos tratamentos direcionados aos alunos considerados "problemas". Ou seja, as escolas comuns solicitavam avaliações para validar diagnósticos de deficiências e os encaminhamentos para escolas especiais.

Além das APAE's, tal fato era comum em outros espaços especializados que encaminhavam crianças com outras deficiências para as respectivas escolas especializadas, de modo a adaptá-los à convivência em sociedade, visando, inclusive, o mercado de trabalho.

Ainda no início da segunda metade do século XX, de acordo com Campos e Martins (2008), em diversos países, os movimentos sociais das pessoas com deficiência, organizados em grandes associações, colaboraram para o surgimento de significativas modificações na área da Educação Especial, incluindo a elaboração de legislação específica com o objetivo de defesa dos interesses desses sujeitos.

Essa mobilização culminou, por volta da década de 1970, início da década de 1980, num movimento integracionista, visando à normalização dos sujeitos com deficiência, em prol da convivência com os demais estudantes. Este novo paradigma considera o direito destes sujeitos à convivência social, ampliando as possibilidades de escolarização de estudantes com deficiência, os quais eram mantidos limitados às instituições de Educação Especial.

Para Sanches e Teodoro (2006), a ideia da normalização viabilizava a permanência em espaços menos segregados, embora de forma ainda segregada. E apesar dos avanços obtidos, estes não provocaram mudanças significavas na sociedade, uma vez que para serem aceitos, os sujeitos com deficiência eram quem deveria adaptar-se ao contexto e às demandas. Entretanto, este movimento impulsionou as bases para a construção do paradigma da Educação Inclusiva, o qual propõe pensarmos espaços escolares capazes de abrigar as diferentes formas de estar e de apreender o mundo.

A proposição de uma educação inclusiva eclode vinculada à ideia de que a diferença entre sujeitos, presente nos processos de aprendizagem, é inexorável aos percursos educativos, e de que a escola deve se estruturar para lidar com as particularidades que envolvem os seres humanos, como suas diferentes condições físicas, sociais, linguísticas, emocionais, intelectuais, dentre outras. Nesse sentido, Gardou (2018) assinala que:

$\mathrm{O}$ adjetivo inclusivo, mais adequado e pertinente, traduz claramente uma dupla recusa. Por um lado, aquela de uma sociedade e de estruturas, da primeira infância à adolescência e da idade adulta à velhice, da qual somente as pessoas "não handicapées" se pensariam proprietárias, fazendo disso seus privilégios ou seus prazeres exclusivos, segundo as palavras de Montesquieu e de Rousseau. Por 
outro lado, a recusa do afastamento, em lugares distantes, daqueles que são julgados incômodos, estranhos, inadequados (p. 26).

Em contraponto, portanto, ao campo da Educação Especial, o discurso de uma educação inclusiva não se fundamenta de modo orgânico no modelo médico-pedagógico, como ocorre com o primeiro, mas na perspectiva do modelo social de deficiência, que se ampara no pressuposto de que as condições de acessibilidade viabilizam a inserção social e educacional das pessoas com deficiência (DINIZ, 2007). Esse movimento, fortemente difundido na segunda metade dos anos de 1990 dada a formalização e circulação da Declaração de Salamanca (UNESCO, 1994), faz com que os princípios de uma educação inclusiva tenham efeitos nas políticas educacionais locais, levando, muitas vezes, à sua revisão. Plaisance (2019) comenta, a esse propósito, que a "noção de inclusão passa a ocupar o primeiro plano e o público-alvo escolar é caracterizado por sua diversidade, não se limitando nem aos alunos em situação de handicap, nem àqueles que têm necessidades especiais" (p. 3). Isso implica na revisão dos processos educativos endereçados a vários sujeitos que vivenciam a experiencia da segregação no interior da escola, seja pela cor da pele, pela situação sócioeconômica, étnica, identitária, dentre outras.

Contudo, se a perspectiva de uma educação inclusiva fomenta o anseio de que a escola se modifique para acolher os alunos, considerando suas diferenças, os últimos anos testemunham os diversos desafios que se colocam na busca pela implementação desse paradigma e que requer a construção de projetos educativos mais coletivos, que envolvam toda a escola no propósito de educar e de viver juntos; práticas educativas acessíveis; elaboração de propostas curriculares e avaliativas mais flexíveis; valorização da dimensão socializatória da educação, bem como da convivência entre pares nesse contexto, dentre outros aspectos.

Em Minas Gerais, alguns movimentos têm sido produzidos nos últimos anos no sentido de ampliar o acesso dos estudantes com deficiência à escola comum, como indicam dados de documentos oficiais publicizados em 2014 e 2020, e que abordaremos no próximo item.

\section{A política de Educação Especial na perspectiva inclusiva em MG}

A Secretaria de Estado de Educação de Minas Gerais (SEEMG), por meio da Diretoria da Educação Especial (DESP), vem desenvolvendo ações que objetivam preparar e adequar as escolas públicas para receber e atender os alunos da Educação Especial, junto aos demais alunos. De acordo com informações disponíveis no site da referida Secretaria ${ }^{1}$, datadas de 2018, as ações são desenvolvidas em quatro eixos principais: promoção da acessibilidade arquitetônica e tecnológica; capacitação de educadores; formação de redes de apoio e garantia dos atendimentos educacionais especializados.

Diante de tal perspectiva, dentro das ações direcionadas para a inclusão dos alunos da Educação Especial, no âmbito de Minas Gerais, foi lançado em 2014, pela SEEMG, o Guia de Orientação da Educação Especial, segundo o qual o atendimento educacional 
especializado se divide em três funções: o Professor de Apoio à Comunicação, Linguagens e Tecnologias Assistivas; o Intérprete de Libras; e o Guia-Intérprete. (MINAS GERAIS, 2014). Como complementação, o Guia previa a implementação de Sala de Recursos Multifuncionais (SRM) no contraturno para atender às crianças com deficiência e a presença do professor de apoio, com o objetivo de "(...) oferecer o apoio pedagógico ao processo de escolarização do aluno com disfunção neuromotora grave, deficiência múltipla ou transtornos globais do desenvolvimento". (MINAS GERAIS, 2014, p. 20).

No início do ano de 2020, a SEEMG publicizou as "Diretrizes para normatização e organização da Educação Especial na rede estadual de Ensino de Minas Gerais”, por meio da resolução SEE No 4.256/2020. Trata-se das "Diretrizes Estaduais da Educação Especial Inclusiva que deverão ser observadas para o atendimento educacional dos estudantes da Educação Especial, matriculados na Rede Estadual de Ensino de Minas Gerais". Nesse documento, a Educação Especial é considerada como uma "modalidade de educação escolar transversal a todos os níveis, anos de escolaridade e modalidades de ensino oferecida preferencialmente na rede regular de ensino, para estudantes com Deficiência, Transtorno do Espectro Autista e Altas Habilidades/Superdotação". A dimensão transversal se mostra alinhada à PNEEPEI (2008), e quanto ao público-alvo, tem-se substituição da categoria Transtornos Globais do Desenvolvimento por Transtorno do Espectro Autista, o que decorre, certamente, das modificações apresentadas pelo DSM-V ${ }^{3}$.

A Resolução confere à Educação Especial o objetivo de garantir aos estudantes da Educação Especial o "direito de acesso às instituições escolares e ao currículo, a permanência e percurso escolar e a uma escolarização de qualidade, por meio da oferta dos atendimentos educacionais especializados". No terceiro capítulo afirma que a "matrícula do estudante público da Educação Especial é compulsória, sendo vedada a possibilidade de negativa de vaga, conforme legislação vigente" (MINAS GERAIS, 2020, p. 1-2).

O documento é afirmativo no sentido de sublinhar a responsabilidade do professor referente pelo "processo de ensino aprendizagem do estudante público da Educação Especial", atribuindo ao professor do Atendimento Educacional Especializado a função de colaborar com esse processo. Nesse sentido, cabe aos professores do AEE: - Eliminar as barreiras que possam impossibilitar a participação dos estudantes da Educação Especial como os demais colegas; - trabalhar de modo colaborativo com o professor regente, planejando recursos de acessibilidade dos estudantes que sejam condizentes ao planejamento previsto; compartilhar na escola o conhecimento do campo da Educação Especial, tecnologias assistivas e comunicação alternativa; - registrar os processos, dentre outras (MINAS GERAIS, 2020).

A Resolução dá visibilidade ao conhecimento específico do professor do AEE, em termos de métodos, técnicas, recursos e procedimentos, ressaltando que eles devem complementar ou suplementar a "formação dos estudantes da Educação Especial para garantir o acesso ao currículo e a qualidade no processo de ensino aprendizagem", o que se mostra próximo aos preceitos da PNEEPEI (BRASIL, 2008).

No que se refere ao Professor de Apoio à Comunicação, Linguagem e Tecnologias Assistivas (ACLTA), o documento esclarece que sua função é "apoiar o processo pedagógico 
de escolarização do estudante com disfunção neuromotora grave, deficiência múltipla ou Transtorno do Espectro Autista (TEA) matriculado na escola comum, sendo autorizado 1 (um) professor para até 3 (três) estudantes matriculados no mesmo ano de escolaridade e frequentes na mesma turma" (MINAS GERAIS, 2020, p. 5).

Percebe-se, nesta resolução, maior ênfase na obrigatoriedade do Plano de Desenvolvimento Individual (PDI), em relação ao documento que a precedeu (MINAS GERAIS, 2014), orientando sua construção a partir da participação de "todos os atores envolvidos no processo de escolarização do estudante", assegurando um articulador para coordenar sua elaboração e registro, bem como apresentando um modelo padrão a ser utilizado nas escolas (MINAS GERAIS, 2020). E ainda destaca a responsabilidade dos gestores das escolas em garantir "reunião semestral com os responsáveis pelos estudantes da Educação Especial com a finalidade de apresentar os direitos e recursos pedagógicos que são disponibilizados aos mesmos" (MINAS GERAIS, 2020). O cumprimento destas diretrizes, da forma como vem previsto, requer um trabalho conjunto entre os professores e demais atores da escola, em colaboração.

Percebe-se também que os dois documentos abordam as escolas especiais de modos distintos. De acordo com as orientações presentes no Guia de Orientação da Educação Especial (SEEMG, 2014), a escola especial, frente ao processo de inclusão, deve transformarse, romper com o papel assistencialista, cujas prioridades eram o cuidado pessoal, a clínica e a socialização dos alunos com deficiências e transtornos globais do desenvolvimento, organizando-se, a partir de então, para o oferecimento de apoio às escolas comuns, através de capacitações dos professores, suporte quanto aos recursos didáticos e tecnológicos específicos e oferecimento de complementação curricular aos alunos da Educação Especial que estão matriculados nas escolas de ensino comum. (MINAS GERAIS, 2014, p. 25)

Já a Resolução que institui as Diretrizes Estaduais da Educação Especial Inclusiva (SEE, 2020), apresenta apenas a definição de escola especial enquanto "aquela que oferta exclusivamente a modalidade de ensino da Educação Especial e atende somente estudantes com Deficiência e Transtorno do Espectro Autista (TEA), comprovados e documentados por profissional da área da saúde"; e orienta quanto ao quantitativo mínimo e máximo de estudantes por turma, menciona o encaminhamento de matrículas e a designação de Auxiliar de Serviços da Educação Básica (ASB) para apoio as atividades de vida diária dos estudantes.

Esta Resolução abrange todos os níveis e modalidades de ensino no estado de Minas Gerais. Entretanto, como reza na Constituição Federal de 1988, especialmente em seu Art. 18, é assegurado aos municípios a condição de ente da federação equiparados aos Estados, Distrito Federal e União, e com igual autonomia. Referente à educação, as instâncias federativas devem organizar, em regime de colaboração, seus próprios sistemas de ensino; sendo possível aos gestores municipais organizarem, em nível local, seu sistema municipal de ensino.

Apresentaremos a seguir as especificidades na rede de ensino municipal de Belo Horizonte, referente ao atendimento dos alunos da Educação Especial. 


\section{A Educação Especial na perspectiva inclusiva em BH}

Em Belo Horizonte, capital de Minas Gerais, o sistema de ensino público gerido pelo município conta com Diretrizes para a Educação Inclusiva estabelecidas em 2004, data anterior à promulgação de PNEEPEI (2008), as quais ainda orientam o atendimento aos alunos da Educação Especial nas escolas comuns.

Tais Diretrizes orientam para a garantia, em todas as escolas do Sistema Municipal de Ensino de: "Língua Brasileira de Sinais; ensino de Língua Portuguesa para surdos; Sistema Braile; Orientação e Mobilidade; Soroban; as ajudas técnicas, incluindo informática educativa; Educação física adaptada; enriquecimento e aprofundamento curricular; atividades da vida autônoma e social" (BELO HORIZONTE, 2004, s/p).

De acordo com as proposições para uma Educação Inclusiva, o Sistema considera o conjunto de profissionais como responsáveis pelos processos de escolarização de todos os estudantes. No que se refere ao percurso escolar dos alunos da Educação Especial (BELO HORIZONTE, 2004, s/p):

Os alunos com deficiência (...) e demais colegas de sala terão registradas todas as propostas pedagógicas organizadas a partir das suas necessidades e habilidades construídas em parceria com os vários atores do processo educativo escolar. Esses registros serão orientadores para se traçar as novas propostas pedagógicas, que terão por eixo as necessidades de cada aluno durante todo o seu percurso escolar. A partir desses apontamentos e das observações cotidianas, os processos de aprendizagens dos alunos estarão em constante avaliação. Alguns alunos podem necessitar ainda, de atendimentos específicos às suas necessidades e ministrados pelo professor especializado, que lhes destinarão os acompanhamentos necessários no espaço escolar após planejamento das propostas com o professor referência $(\mathrm{s} / \mathrm{p})$.

Alinhada à política nacional, em 2009 é promulgada Portaria ${ }^{4}$ que fixa normas para organização e funcionamento do atendimento educacional especializado na Rede, em caráter complementar/suplementar e não substitutivo, temporário e não obrigatório. Seu funcionamento fica submetido à atuação e articulação de diferentes equipes de trabalho: "I equipe GCPF/Inclusão da Pessoa com Deficiência; II - equipe de Apoio à Inclusão; III equipe de Professores do AEE; IV - equipe de Assistentes do AEE" (BELO HORIZONTE, $2009, \mathrm{~s} / \mathrm{p})$.

Em 2016, a Lei n 10.917 aprova o Plano Municipal de Educação de Belo Horizonte e dá outras providências, incluindo-se as pessoas com deficiência em todas as metas previstas para a qualidade da educação no município; com destaque na meta 7, para a universalização do acesso à educação básica e ao atendimento educacional especializado para a população de 4 (quatro) a 17 (dezessete) - público da Educação Especial, preferencialmente na rede regular de ensino, com a garantia de sistema educacional inclusivo, de salas de recursos multifuncionais, classes, escolas ou serviços especializados, públicos ou conveniados. Para tal, entre outras, pontua como estratégia manter, ampliar e monitorar a articulação 
intersetorial entre professores e equipes multiprofissionais no acompanhamento de estudantes da Educação Especial (BELO HORIZONTE, 2016, s/p).

A partir das orientações, a rede municipal prioriza o atendimento educacional especializado oferecido nas salas de recursos multifuncionais, onde consta, além do material disponível, o professor de AEE e instrutores específicos - Libras, Sistema Braile, entre outros. Nas salas de aula comum, além do tradutor/intérprete de Libras, quando necessário, tem-se ainda a participação de um profissional de apoio, o qual auxilia estudantes da Educação Especial que necessitam de suporte para permanecerem em sala de aula, para a comunicação, locomoção, alimentação, higiene; para realizarem as atividades e interagirem com a turma. Apesar desse professional não ser um professor, nem mesmo ter responsabilidades com o conteúdo pedagógico, torna-se peça importante na mediação entre o estudante e os objetos de aprendizagem.

Independentemente das peculiaridades vigentes na organização das duas redes de ensino citadas, para que o atendimento do estudante da Educação Especial seja efetivo, faz-se necessário que o trabalho entre os professionais envolvidos ocorra em caráter de colaboração. Entretanto, apesar de se constatar avanços nas políticas públicas, na formação de professores e na estrutura das escolas, deparamo-nos com dificuldades na realização de um trabalho conjunto por parte dos profissionais responsáveis pela aprendizagem e desenvolvimento do aluno da Educação Especial, fundamental à efetivação da escolarização destes, numa perspectiva inclusiva.

\section{A emergência do trabalho colaborativo para a efetivação da Educação Especial na perspectiva Inclusiva}

Os documentos oficiais produzidos no Brasil após a emergência da perspectiva inclusiva, e mesmo documentos internacionais que difundem essa visão, como a Declaração de Salamanca (1994), reclamam a relevância da dimensão cooperativa e do trabalho coletivo entre equipes para a efetivação de uma escola mais acolhedora às diferenças que os sujeitos apresentam. Muitas vezes, esses documentos partem da consideração que o trabalho na escola seja essencialmente coletivo, que haja uma parceria já estabelecida entre os profissionais (MEC, 2008; BRASIL, 2011; MINAS GERAIS, 2014; 2020; BELO HORIZONTE, 2004; 2009) e evidenciam a centralidade desse aspecto para a efetivação de suas proposições, enquanto a literatura sinaliza, ao contrário, os desafios dessa dimensão para o cotidiano das práticas educativas.

Em relação aos desafios do trabalho colaborativo em um contexto no qual predomina uma perspectiva de centralidade na atuação do AEE, tal como previsto na PNEEPEI (2008), Christo e Mendes (2018) apresentam dados de um levantamento bibliográfico realizado sobre o tema em artigos científicos publicados entre 2012 e 2016. As autoras partem da conceituação de Damiani (2008), a qual envolve apoio mútuo, objetivos comuns negociados pelo coletivo e corresponsabilidade pela condução das ações, e discutem o fato de que os artigos analisados evidenciam uma aposta das pesquisas nos benefícios que essa perspectiva poderia significar para o processo de inclusão escolar, tendo em vista haver no Brasil uma desarticulação entre o trabalho do professor de educação geral (referência das turmas ou das 
áreas do conhecimento) e o professor da Educação Especial (professor de apoio ou professor da SRM).

Vilaronga e Mendes (2014) apresentam uma pesquisa realizada em escolas do município de São Carlos (SP), onde constatam a necessidade da proposta de um ensino colaborativo ou coensino, que consiste em práticas colaborativas entre os professores especializados e os da sala comum, para o apoio à inclusão escolar. Concluem que a literatura científica relacionada a esta proposta, apesar de promissora, evidencia a necessidade de mais estudos sobre a colaboração entre estes profissionais nas escolas. Destacam que é preciso discutir na escola questões relacionadas ao tempo de planejamento em comum entre os profissionais; aos conteúdos que devem ser incluídos no currículo; às adaptações curriculares; à distribuição de tarefas e responsabilidades; às formas de avaliação; às experiências em sala de aula; aos procedimentos para organização da sala, à comunicação com alunos, pais e administradores; ao acompanhamento do progresso de aprendizagem dos alunos; às metas para o Plano Educacional Individualizado dos alunos com deficiência (VILARONGA; MENDES, 2014).

O termo colaboração pode ser pensado a partir de outros termos similares como cooperação, coparticipação, parceria, coletivo, em conjunto. Trata-se aqui, neste trabalho, apenas de uma escolha semântica, e não de uma definição própria, pronta, nem mesmo de uma prescrição do que seja um trabalho colaborativo.

Boaventura (2019), em sua pesquisa que buscou situar os desafios do exercício da função das professoras de apoio à inclusão, nas escolas da rede pública estadual de MG, desenvolve uma longa discussão acerca do trabalho colaborativo, apresentando diversas definições presentes do campo da educação, bem como discutindo as práticas colaborativas constituídas em outros países - Itália e Portugal - para a educação das pessoas com deficiência nas escolas comuns. Chama-nos a atenção o que o autor cita de Hargreaves (1998), quando diz que a colaboração promove um "desenvolvimento para além da reflexão pessoal e idiossincrática, ou da dependência em relação a peritos externos, fazendo com que os professores aprendam uns com os outros, partilhando e desenvolvendo em conjunto as suas competências" (HARGREAVES, 1998, p. 209 apud BOAVENTURA, 2019, p. 64).

Os conceitos vigentes nos trabalhos citados até aqui (VILARONGA; MENDES, 2014; BOAVENTURA; 2019; DAMIANI, 2008), dialogam com o que está posto para os professores nas políticas públicas do estado de $\mathrm{MG}$ e do munícipio de $\mathrm{BH}$, foco de nossa investigação. No estado coexistem dois professores na sala de aula comum (um regente e um de apoio à Comunicação, Linguagem e Tecnologias Assistivas - ACLTA), para o atendimento do aluno com deficiência, bem como o professor de AEE, que o atende no contraturno, em sala de recursos multifuncionais, quando necessário. No município, o professor regente conta com um monitor de apoio em sala acompanhando o aluno, quando necessário, enquanto o professor especializado atende ao aluno no contraturno, na sala de recursos multifuncionais. Todavia, como indica o trabalho de Boaventura (2019) ao abordar o professor de apoio do estado de MG, nem sempre as orientações prescritas pelas políticas públicas são possíveis de serem efetivadas no contexto escolar.

Independentemente do modelo, o que se verifica é um descompasso entre o que prospectam as políticas e os desafios reais das escolas sinalizados na literatura científica. Esse 
descompasso parece indicar que, a despeito dos avanços que o campo educacional alcançou nas últimas décadas - em termos de gestão, organização do trabalho pedagógico, formação e tecnologia -, dimensões elementares, relacionadas a uma aproximação entre profissionais e à construção de trabalhos mais colaborativos, permanecem como desafio. É como se colocar em prática algumas medidas, como desenvolver um trabalho conjunto, em parceria, não hierarquizado, que passasse pela discussão partilhada de casos, demandassem não apenas uma disponibilização do sujeito para as ações práticas, mas outros posicionamentos subjetivos em relação aos colegas e aos estudantes nessas ações.

Tal constatação não surpreende o saber psicanalítico, que confere justamente à relação entre os sujeitos uma das mais importantes fontes de sofrimento (FREUD, 1921), o que não tem lugar no texto das orientações e normatizações continuamente publicadas. Nesse sentido, o ato de estar com o outro, de planejar ações que colocarão em questão as concepções e práticas de cada profissional, não são detalhes que poderiam ser minimizados de acordo com o perfil de cada gestão escolar ou desconsiderados no processo de construção de uma educação democrática. A dimensão artesanal que parece subjacente à proposição de uma educação inclusiva, porém pouco reconhecida nesse contexto (SILVA, 2014), é a mesma que deveria se atentar à diversidade dos sujeitos professores nesse processo, inquietando-nos diante dos (des)caminhos que produzem tal realidade.

A impossibilidade do encontro entre os profissionais para a construção dos processos educativos dos estudantes da Educação Especial impacta diretamente na efetivação do que preconizam a políticas e a legislação. Os motivos para este desencontro certamente não são poucos. Podemos citar questões objetivas que perpassam aspectos históricos, econômicos, sociais, organizacionais entre tantos. No entanto, este trabalho pretende chamar a atenção para o que está mais além das questões objetivas e que possa culminar em impasses na interlocução entre estes profissionais no espaço escolar. Interessa-nos aqui destacar elementos da dimensão do sujeito, que escapam às normativas e que só podem ser tratados no um a um.

\section{Uma contribuição da psicanálise à Educação}

Se os trabalhos acadêmicos são enfáticos em indicar os desafios presentes na construção de uma escola mais democrática e aberta às diferenças, em termos de infraestrutura, valorização profissional, gestão e práticas pedagógicas, a psicanálise nos ajuda a identificar outros fatores que podem comparecer na produção desses impasses, por vezes de modo mais sutil, porém não menos incessante.

Uma contribuição da Psicanálise à educação consiste na consideração da subjetividade e do desejo em relação ao conhecimento e às aprendizagens, como motor da atividade simbólica. Trata-se de uma alternativa à hegemonia de referenciais teóricos centrados nas capacidades do organismo para a aquisição e tratamento das informações. Para além da coerência, é preciso levar em conta o sujeito do inconsciente que se manifesta, sobretudo, por meio de faltas, atos falhos, sintomas, manifestações que não cessam de se escrever (LACAN, 1972-1973) e que evidenciam a força do real na vida institucional dos sujeitos. O 
real tomado aqui na perspectiva do nó borromeano, que atesta a sua existência enodada às dimensões do simbólico e do imaginário, ao mesmo tempo em que demarca a existência de algo cuja representação na realidade psíquica mostra-se impossível (CAPANEMA; VORCARO, 2017). O real marca aquilo que escapa ao controle do sujeito em termos de atos, palavras ou mesmo no padecimento do seu próprio corpo, quando outras possibilidades simbólicas e imaginárias se esgotam.

Esses elementos, distantes, em geral, das propostas estabelecidas em plano macro, presentificam-se, entretanto, no cotidiano das práticas, quando tudo parece simples, menos a disposição dos sujeitos em efetivá-las. O real se mostra, então, como motor do mal-estar, expressando sentimentos de insatisfação que fazem com que os sujeitos se indisponham a fazer o que lhes é pedido ou a agirem conforme ditam os protocolos institucionais, mesmo que, aparentemente, mostrem-se mais abertos às mudanças propostas.

Freud concebeu a tarefa educativa, juntamente com a de psicanalisar e a de governar como do campo impossível. Isso se refere ao impossível do alcance ao que interfere no outro. A partir do equívoco que constitui a estrutura da linguagem, bem como dos invisíveis da transmissão, a tarefa educativa congrega algo do não-toda que, nos ambientes heterogêneos da educação para todos, promove a angústia e a desistência diante do ensinar (NEVES, 2014). O paradigma da Educação Inclusiva impôs novos desafios aos professores, os quais, diante de algumas poucas tentativas fracassadas, constituintes do ato de educar, se angustiam ou se alienam em certezas, tais como "eu não fui formado para isso". Cada vez mais, os professores deixam de recorrer a um saber que compõe seu desejo pela profissão e, ao invés de serem mobilizados pelo desafio, acabam por ficar paralisados no discurso da impotência.

A prática docente pode ser facilmente reduzida, assim, a uma lista de procedimentos ou protocolos diante das quais os educadores passam a se curvar mediante demandas contingenciais diversas, o que não ocorre sem consequência para o sujeito, à medida em que o afasta das suas significações e sentidos, extraindo de sua ação a manifestação de sua autoralidade.

Anjos, Andrade e Pereira (2009), em pesquisa que analisou os discursos presentes e em enfrentamento nas falas dos professores responsáveis pelo atendimento de alunos com deficiência, numa experiência de inclusão escolar, destacam:

(...) separando o seu fazer do fazer coletivo, o professor passa a entender a inclusão como tarefa somente sua, circunscrita aos limites do pedagógico e imposta a partir de forças externas. Assim, a produção de processos excludentes não é enfrentada, e o processo inclusivo limitado à sala de aula ou, na melhor das hipóteses, à escola está fadado ao fracasso $(2009$, p.127)

Desse modo, sem espaços que acolham as questões que advêm do sujeito ou individualizando uma discussão que, na realidade, vincula sujeito e dimensão institucional, os professores trafegam de uma escola a outra sem tempo para refletir, interrogar seu desejo ou construir um saber-fazer diante de um aluno que apresenta necessidades educacionais 
especiais. Acreditando que o saber para tal está fora, em algum lugar, ao qual ele não acede (MRECH, 2003), como a questão da medicalização da educação insistentemente nos indica.

Atentas a esse movimento, Bastos e Kupfer (2010) sublinham que o "trabalho de inclusão escolar não pode ser realizado sem a inclusão dos professores, já que eles são uma das ferramentas mais importantes na sustentação desse lugar social que se pretende oferecer à criança psicótica: o lugar de aluno" (p. 117). Embora as autoras estejam abordando a função docente na escolarização de crianças que apresentam particularidades na constituição do laço social, entendemos que sua colocação pode ser ampliada para outros percursos de inserção escolar, pois evidencia a posição de relevância que os professores ocupam nesse processo e a premência de que eles sejam reconhecidos e escutados desse lugar.

\section{A Conversação como metodologia de pesquisa em educação}

É a partir desta discussão que vem sendo desenvolvida uma pesquisa-intervenção direcionada aos impasses na efetivação de um trabalho em colaboração (ou colaborativo), envolvendo os professores da sala comum, professores do atendimento educacional especializado e demais envolvidos, enquanto premissa para o atendimento dos estudantes da Educação Especial na perspectiva inclusiva.

Pode-se dizer, a pesquisa-intervenção consiste em uma das modalidades das pesquisas participantes que buscam investigar a vida de coletividades em sua diversidade qualitativa, assumindo uma intervenção de caráter sócio analítico (ROCHA; AGUIAR, 2003).

Tendo como referência a Psicanálise, Teixeira (2010) nomeia esse modelo de investigação como Metodologia em Ato. O autor parte do pressuposto de haver, na Psicanálise, uma relação indissociável entre investigação e tratamento, defendendo que "o saber que rege a pesquisa emerge como efeito de sua colocação em ato. Por mais que o pesquisador possa se orientar por algum saber anterior, é o saber do caso no momento pontual de sua colocação em ato que opera mudança" (p. 28).

Este é o pressuposto da Conversação que, nesta perspectiva, pode ser pensada como um dispositivo clínico passível de ser utilizado enquanto recurso metodológico nesta modalidade de pesquisa. Sua origem, de acordo com Mesquita (2017), diz respeito aos encontros clínicos do Campo Freudiano, iniciados na década de 1990, promovendo o debate entre os participantes do $\mathrm{CIEN}^{5}$ em torno dos temas cruciais da psicanálise, para lidar com questões que não têm saída prévia e que somente poderão ser construídas a partir daquela conversa.

A Conversação de orientação psicanalítica passa então a ser utilizada para além de sua vertente puramente clínica, ocupando também função metodológica em pesquisas no campo da psicanálise aplicada ao social - no caso aqui tratado, às escolas - onde algo não vai bem, a partir de uma queixa que, por vezes, pode ser tomada como sintoma (SANTIAGO; MIRANDA; VASCONCELOS, 2006).

Embora o que mais se descreve como prática da psicanálise seja a "escuta", o que se realiza na Conversação é a "leitura" de um sintoma, procedimento não só desenvolvido pelo analista, mas também transmitido àquele que pode falar de seu mal-estar (SANTIAGO; 
ASSIS, 2018, p. 33). A Conversação oferece uma oportunidade para que algo da subjetividade possa introduzir-se e circular no discurso dos participantes do grupo; partindose do pressuposto de que falar com alguém também é, para aquele que fala, um momento para escutar-se, posto que aquilo que é dito interpela o falante na sua relação com seu desejo (PALHARES; BASTOS, 2017).

Palhares e Bastos (2017, p.251), ao abordarem pesquisas que partem da escuta de professores "dando-lhes a palavra para que possam dizer sobre seus sofrimentos e sobre o mal-estar docente", destacam que a especificidade da orientação psicanalítica é apostar que o "questionamento dos professores recaem sobre si mesmos, a partir da fala que o sujeito endereça a um outro" (p. 257). Ao pensarem a Conversação como um dos dispositivos para formação de professores que incluem a dimensão do sujeito, apontam-na como um modo de reflexão sobre a prática. Entretanto, diferentemente da perspectiva do professor-reflexivo, que comparece nos textos de diversos autores do campo da educação, nesta, o professor vêse diante de questionamentos acerca de "o quê", de seu próprio desejo e de suas próprias angústias, está implicado em seu fazer docente.

A especificidade da Conversação de orientação psicanalítica diz respeito à participação das singularidades na mobilização dos significantes que surgem no conjunto, de modo a provocar vazios, reconhecer as falhas constituintes também do conhecimento técnico pedagógico, a fazer emergir perspectivas inéditas do todo - do grupo, bem como a invenção de cada um. Nesse sentido, no campo da educação, pode ser pensada como dispositivo utilizado em pesquisas-intervenção que visam à formação dos professores participantes; bem como metodologia de pesquisa-intervenção que traz como objetivo não somente constatar os sintomas escolares, mas também aprender sobre estes a partir dos sujeitos envolvidos, além de congregar a aposta numa intervenção que aponte algo inédito (NEVES, 2014).

Nesta última perspectiva, podem-se citar algumas trabalhos já desenvolvidas a partir do uso das Conversações de orientação psicanalítica, com foco nos professores, nos estudantes ou nos gestores; entre elas Santiago (2008), Miranda (2006; 2010), Santos (2009), Vasconcelos (2010), Neves (2014), Mariás (2015), Mesquita (2017), Lima e Kelles (2017).

Tendo também como referência tais trabalhos, supõe-se que a pesquisa-intervenção de orientação psicanalítica, a partir da Conversação, possa nos ensinar algo sobre esses professores, em especial no que se refere aos desafios diante do trabalho com alunos da Educação Especial na escola regular, os quais aparecem na impossibilidade do engajamento no trabalho colaborativo.

\section{Conversação com professores: os desafios do Trabalho Colaborativo na perspectiva inclusiva}

Dentre os desafios da Educação Especial na perspectiva da educação inclusiva, focamos aqui os desafios para a efetivação de um trabalho colaborativo entre os professores da classe regular e do atendimento educacional especializado. Interessa-nos levantar aquilo que se refere a elementos da subjetividade que constituem os sujeitos professores, os quais possam culminar em impasses - 
na interlocução entre estes profissionais no espaço escolar; na capacidade de transmissão; e assim, consequentemente, no desenvolvimento dos alunos envolvidos, os quais acabam muitas vezes permanecendo excluídos das possibilidades de aprendizagem.

Para tal, levantou-se escolas comuns da rede pública de $\mathrm{BH}$, as quais contam com uma infraestrutura considerada adequada: salas de AEE devidamente equipadas e localizadas dentro do próprio prédio da escola, profissionais capacitados para o atendimento especializado, além de tempos e espaços suficientes para a sistematização de reuniões e encontros entre os professores responsáveis por pelo menos um mesmo aluno - na sala regular e sala de AEE. Desse modo, buscando-se minimizar justificativas calcadas na estrutura do espaço educacional.

Após contato com tais escolas, elegeu-se inicialmente três entre aquelas que aceitaram a oferta da pesquisa e que reconheceram suas dificuldades na efetivação de um trabalho colaborativo para a inclusão do aluno da Educação Especial.

A pesquisa ${ }^{6}$ se efetiva, portanto, a partir de um conjunto de três sessões de Conversação consecutivas, conduzidas pelas pesquisadoras, com uma hora de duração, uma vez por semana, com grupos de professores nas primeiras três escolas eleitas. O número de sessões diz respeito a elementos objetivos, como a dificuldade em encontrar tempo comum disponível nas escolas para mobilizar um grupo grande de professores; e elementos clínicos, inspirados na noção de tempo lógico de Lacan. Este, nos Escritos (1998), traz um problema de lógica, uma reflexão sobre o tempo, a partir da apresentação de três instâncias constitutivas em um processo de sofisma. A modulação desse tempo consiste nos seguintes momentos da evidência: o instante de olhar, o tempo para compreender e o momento de concluir.

A $1^{a}$ Conversação consistiu no momento de ofertar o espaço aos participantes, que, de modo geral, nesta pesquisa, fizeram uso do tempo para apresentarem suas dificuldades, as quais são calcadas em elementos externos a si mesmos - a formação, a quantidade de estudantes na sala de aula, os turnos de trabalho, o modelo de atendimento adotado pela escola - entremeados por alguns vacilos em relação às suas próprias certezas quanto às impossibilidades no trabalho colaborativo. A $2^{\mathrm{a}}$ Conversação, pode-se dizer, envolveu menor necessidade de exposição de suas queixas e denúncias, permitindo-se a diluição do excesso de sentidos para interrogarem suas certezas, a partir do que lhes foi possível escutar daquilo lhes foi devolvido em relação ao $1^{\circ}$ encontro. Na $3^{a}$ Conversação, já anunciada como último tempo daquele ciclo, na maior parte das vezes foi onde se viu precipitar algo inédito para $o$ grupo a partir do reconhecimento das próprias invenções cotidianas.

Cada Conversação é gravada, com a permissão dos participantes, e posteriormente transcrita, de modo que se possa recolher os elementos das falas, os quais são retomados como ponto de partida para o encontro seguinte.

Passaremos a relatar um recorte do percurso das Conversações realizadas com dois grupos de professores - respectivamente, em uma escola da rede municipal e outra da rede estadual de ensino. Para tal, foram selecionados alguns fragmentos que apresentam o percurso das três Conversações realizadas com um dos grupos, bem como fragmentos do percurso de uma das Conversações com o outro grupo, os quais nos permitem tecer algumas considerações que motivaram o presente artigo. 


\section{A $1^{\underline{a}}$ escola-o grupo $A$}

A $1^{\mathrm{a}}$ escola, pertencente à rede municipal de ensino, fora construída há 10 anos, fruto de luta da comunidade (orçamento participativo). Teve em seu projeto arquitetônico a previsão do cuidado à acessibilidade das pessoas com deficiência. Conta com uma SRM ampla e bem equipada, com duas professoras licenciadas e especializadas, que atendem ao público da Educação Especial; e ainda com profissionais de apoio (Auxiliares de Apoio à Inclusão) para os alunos cuja demanda de acompanhamento esteja justificada por laudo médico. Os professores da sala regular contam com 5 horas semanais (1 por dia) para Atividades Coletivas de Planejamento, Avaliação e Acompanhamento do Trabalho Escolar (ACPATE), conforme a Lei municipal 7577/98.

A gestora mostrou-se sensível às demandas da Educação Especial na perspectiva da Educação Inclusiva; e buscava no momento da oferta da pesquisa, ações que pudessem proporcionar maior engajamento dos professores para trabalharem de modo colaborativo, tendo em vista sobretudo as queixas apresentadas pelas professoras de AEE em relação ao afastamento dos demais professores.

Constituíram-se, por adesão, 2 grupos de docentes, 1 em cada turno (manhã/tarde). Serão descritos aqui alguns fragmentos do percurso das 3 Conversações realizadas junto a um dos grupos, o qual foi constituído de 5 professoras do $1^{\circ}$ Ciclo do Ensino Fundamental - 2 alfabetizadoras, 1 de Língua Portuguesa e 2 professoras especializadas (AEE) as quais trabalham com os alunos das classes das outras 3 professoras.

O percurso da Conversação teve início com a discussão sobre a falta de formação, a implementação da política no município e a frustração diante do modo como a inclusão vem ocorrendo. Percebeu-se desinformação sobre o trabalho do AEE, bem como sobre os alunos atendidos nesse espaço. Enfatizaram a impossibilidade do trabalho conjunto em função da falta de tempo e de não saberem onde recorrer para tal. Ou seja, destacam-se no encontro falas que associam a impossibilidade a algo que se encontra fora dos sujeitos, para além do que se possa fazer, constituindo certezas e imobilidade.

Palhares e Bastos (2017) ressaltam que o "manejo da discussão, orientado pela ideia de giro discursivo, proposta por Lacan (1992) em sua teoria dos discursos, pode levar o trabalho na direção de uma aquisição de saber com implicação de sujeito e, portanto, com mais significação e efetividade para a prática" (p. 261).

No $2^{\circ}$ encontro, a fala das professoras se reorganiza e transita para o privado, para aquilo que não diz respeito ao outro, mas a si próprias, ainda que coletivizado. Demonstram um mal estar atrelado à impotência diante do que lhes causa enigma e sobre o qual não conseguem dizer: "Eu não sei lidar com uma criança que eu não consigo saber o que ela aprende". Mas logo expressam a demanda por algo que possa ajudá-las, ainda que este auxílio seja a nomeação do "faltante" no outro - o diagnóstico. Interpeladas quanto a isso, que vem tentar responder ao enigma, afirmam: "O laudo é o nosso Norte".

Em um movimento para mascarar e recobrir a experiência de ambivalência e mal-estar, percebe-se uma tentativa de naturalizar as diferenças dos alunos com deficiência e enquadrá- 
los em categorias ordenadoras previamente estabelecidas, que pressupõem uma descrição detalhada e cada vez mais refinada, em um movimento classificatório que tende ao infinito. Este aluno então passa a produzir, no professor, uma ausência de nomeações, um estranhamento, e a angústia passa a tomar conta da cena escolar. As suas dificuldades provocam incertezas que impossibilitam a viabilidade do exercício docente, passando o educador a questionar isoladamente o seu trabalho, julgando não ter os conhecimentos necessários para uma atuação mais assertiva em relação a esses alunos.

A partir deste ponto, a Conversação segue com as professoras dizendo dos alunos específicos que causavam mal-estar a cada uma delas. Passaram então a falar da falta de escolha versus a escolha por trabalhar com "este público"; ou seja, o direito do aluno em estar na escola e a falta de direito do professor em se recusar o trabalho com estes sujeitos que explicitam a falta no corpo, causando-lhes estranhamento.

Podemos pensar que a chegada do aluno da Educação Especial no contexto do ensino comum evoca uma quebra no esperado ou previsto, sendo necessário ao professor, por vezes, se haver com um estranhamento. Freud, em 1919 (2019), nos apresenta o texto intitulado "Das Unheimliche", um termo em alemão que comporta sentidos como: aquilo que é não familiar, indomesticado, estranho, inquietante ou ainda estranho-familiar. Nesse texto Freud mostra que aquilo que se apresenta como estranho, aparentemente desconhecido, na verdade já foi conhecido um dia. A oposição aparente aponta - de forma paradoxal - uma equivalência entre estranho e familiar. "Das Unheimliche" seria a assustadora impressão que se liga às coisas conhecidas e familiares desde sempre e, nesse sentido, é o efeito do retorno do que fora recalcado, onde nos colocamos face a face com o outro desconhecido e com o que há de desconhecido em nós.

Para além do imaginário que nomeia esse corpo como "este público", aparece na $3^{\mathrm{a}}$ Conversação a angústia e a frustração das professoras quando não se consegue alcançar a aprendizagem em um aluno, mesmo após o uso de diversos recursos. Citam casos presentes ao longo de suas histórias profissionais, referentes aos alunos sem deficiência, os quais as marcaram pelo encontro com o impossível no ato de educar. Nesse ponto da Conversação, as professoras elaboram a evidência desse impossível no trabalho com um sujeito com deficiência - este estranho familiar. Desvestidas do discurso da ineficácia da estrutura, da formação e da organização, as professoras apresentam um novo giro discursivo e concluem a Conversação retificando a frase do encontro anterior: "O laudo é o nosso Álibi".

Este grupo, que revelou ter se beneficiado do espaço proporcionado pela pesquisa, demonstrou a presença de uma recusa ao trabalho em colaboração com as professoras de AEE, tendo em vista o reconhecimento da possibilidade de realizá-lo. Recusa esta que pode ser pensada como uma solução para se evitar o contato com a angústia da tarefa "não toda" da educação, explicitada na "falta" evidenciada pela deficiência. Ao se abordar as possíveis causas da constatada dificuldade nesse coensino, as professoras reconheceram a dificuldade em lidar com o real do corpo faltoso, revelando um ponto impossível de se lidar; bem como a dificuldade em articular seu desejo a algo que consideram excluído de suas escolhas pela docência - a pessoa com deficiência 
No momento de concluir, as professoras apresentam a demanda endereçada à coordenação para a instituição na escola de um espaço de fala, de um encontro com todo o coletivo da escola para tratarem o problema e buscarem soluções de modo conjunto. Cabe destacar, Mesquita (2017) também registra demanda similar, por parte de professores, em pesquisa realizada em escola pública da rede estadual, a qual contou com uso de metodologias de orientação psicanalítica, entre elas Conversação com o corpo decente para a discussão de casos de alunos da Educação Especial. Podemos pensar que os momentos coletivos da escola pouco incluem a singularidade dos docentes.

\section{$A 2^{a}$ escola - o grupo $B$}

A $2^{\mathrm{a}}$ escola, pertencente à rede estadual de ensino, fora construída há cerca de 40 anos, contando hoje com mais de 850 alunos nos anos finais do Ensino Fundamental e no Ensino Médio. É reconhecida como uma escola tradicional na região onde está localizada e considerada como modelo na referida rede. Possui uma SRM pouco usada e uma professora licenciada e especializada, que lá atende os sujeitos da Educação Especial; conta com acompanhantes para alguns casos; e Professoras de Apoio, especializadas, junto aos alunos da Educação Especial dentro da sala de aula. Os professores da sala regular devem, a cada 50 minutos de trabalho, dedicar 15 minutos em atividades referentes à escola/disciplina.

Além da diretora geral, a escola conta com 3 grupos de gestores, um em cada turno. A pesquisa foi aceita pela gestão, embora tenha havido dificuldades para organizar um grupo de professores para o trabalho. Constituiu-se então, por adesão, um grupo de 15 docentes do $8^{\circ}$ e $9^{\circ}$ ano do Ensino Fundamental, numa manhã de sábado letivo, com o qual foi feito um encontro de Conversação diagnóstica, de modo a interrogar a relação com o trabalho colaborativo entre os professores das salas regulares, professores de apoio e de AEE.

O percurso da Conversação teve início com a exposição dos professores em relação à falta de formação para o trabalho com os alunos com deficiência. Todos queriam falar, configurando um encontro inicialmente tumultuado, com muita queixa e pouca escuta.

Da falta de formação, questionada pelas professoras de apoio, que colocaram as possibilidades de informação e busca de parcerias, os professores de sala regular passaram a falar das dificuldades em avaliar os alunos "com laudo" a partir dos parâmetros que os orientam; de modo que não conseguem verificar o progresso destes. A professora de AEE conta o caso de uma aluna com deficiência, cuja mãe reconhece os avanços da filha desde que entrou para a escola, quando passou a participar mais dos assuntos em casa, tornou-se mais vaidosa e fez amigos.

A professora de Matemática então pede a palavra, minimizando o tumulto:

A gente, professora, a gente tem essa... coisa do aprendizado. O que move. Mas por exemplo, os sem laudo. Eu tenho o $8^{\circ}$ ano que é difícil no sentido de comportamento, mas são meninos muito bons. Eu faço perguntas de uma aula que eu dei há duas semanas e os meninos respondem tudo. Eu fico em êxtase. Eu fico louca. A gente quer é... Então a gente quer ver um retorno desses nos meninos. 
Na sequência, toma a palavra a professora de Biologia, a qual passa a ser ouvida por todos atentamente:

A gente tem que ver o que a (AEE) colocou também. A gente não vê o avanço dele em questão acho que de nota, a gente tem que ver os avanços que eles fazem. Igual o aluno que ela citou que não saia de casa. Então a gente tem que ver que, às vezes eles não tem com a gente, mas na sociedade eles estão melhorando, eles estão avançando.

\section{Segue a professora de Física:}

Porque nós temos que trabalhar em equipe. E eu vou pontuar... o Raul. Tinha uma professora de apoio que estava trazendo algumas atividades do ensino fundamental I pra ele colorir. Eu cheguei na carteira dele e ele falou baixinho, "Professora, só eu, só eu”. Nesse dia eu saí daqui arrasada. É isso que é a minha angústia. Nós estamos tapeando o aluno, falando - você é limitado e você vai aprender só colorir e fazer ligação. O Raul seria competente, ele tem condições de crescer, no limite dele. E u não posso fazer nada. É por isso que nós nos sentimos angustiadas. Porque nós temos 50 minutos, infelizmente. E os outros 39 alunos? Se eu for só atende-lo eu vou ser a professora de recurso dele. Eu não posso, então assim...

Uma das professoras de Apoio rebate:

Não! A inclusão, não é você ir lá e pegar com o professor do Fundamental I uma outra atividade. Não é gente. Isso aí quem tem que fazer é o professor de apoio, em outro momento, mas aquele momento lá que você tá dando logaritmo, que você tá dando... o seu aluno de alguma forma ele tem que fazer. Essa foi a inclusão que eu aprendi. Mas não é fácil pra gente que é professor de apoio colocar no papel se a gente não tem vocês, porque eu sou professora, eu formei em pedagogia, não formei em matemática, não formei em inglês, não formei em física... Então, se eu não tiver esse contato, a gente não consegue. (Profa. de apoio 1

Outra professora de Apoio se pronuncia em tom de desabafo:

Pra gente que é professor de apoio também. Não tem coisa pior que o professor passar por você que é o professor de apoio e seu aluno aqui ó... isso não tem coisa pior pra gente. Porque a gente se sente assim... o que que eu tô fazendo aqui dentro dessa sala? Você não tem prazer de ficar na aula do professor. $O$ professor, além de ele não enxergar o seu aluno, ele não enxerga você. Ele não te enxerga. Porque ele nem te perguntou, é... é pra passar a folha? Porque tem professor que ele ainda te pergunta, mas tem professor que ele nem te olha. (Profa. de Apoio 2) 
Esta professora chama a atenção para o fato de se sentir excluída juntamente com o aluno da Educação Especial na sala de aula durante algumas disciplinas. Esta queixa é apresentada pela primeira vez aos professores regulares, segundo elas mesmas. Trata-se de aspecto significativo ao se pensar a ausência de um trabalho colaborativo, uma vez que o professor colaborador passa a compor a invisibilidade construída para o aluno que visibiliza o impossível de educar.

Em pesquisa sobre a atuação do professor de apoio (MINAS GERAIS, 2014) em escolas estaduais situadas em Belo Horizonte, Boaventura Júnior (2019) explora a dimensão colaborativa prevista para essa função, que demandaria uma articulação entre o profissional que ocupa o lugar de referência para as turmas e aquele que realiza um trabalho de apoio, voltado para o acompanhamento dos estudantes que necessitam de suportes mais contínuos em seu percurso. O autor (2019) evidencia em seu estudo o quanto as professoras de apoio careciam de reconhecimento por parte de seus pares, ocupando, em geral, a posição de cuidadoras dos alunos acompanhados. Suas intervenções não apresentavam articulação com as propostas pedagógicas direcionadas tanto para as turmas, quanto para esses estudantes, em uma rotina de trabalho muito distante do que pressupõe a perspectiva de prática colaborativa em relação aos estudantes da educação especial, compostos, naquele momento, por sujeitos com disfunção neuromotora grave, deficiência múltipla e transtornos globais do desenvolvimento (MINAS GERAIS, 2014).

A professora de Apoio 1 retoma:

Você falou da formação. Eu tenho a formação, meu curso todo, todo, eu vi a Educação Especial. Mas eu aprendi? Aprendi, gente, mas foi aqui, na prática. Sabe por quê? Porque eu não aprendi, ah... é... essa criança tem autismo e tudo sobre um aluno. E cada criança é diferente. Por exemplo, a Iasmin, eu peguei ela a partir de Agosto. Agosto, setembro e outubro, agora que eu aprendi a trabalhar com a... a Iasmin. Agora. E o seu olho brilha! Porque assim, você vê que o seu trabalho tá... tá fluindo. Seu olho brilha!

Imediatamente a professora de Matemática acrescenta:

Então, eu quero que meus olhos brilhem! Esse é o problema. E eu queria colocar, que eu acho que a pergunta que você fez pra ela é... Mas ela não te respondeu. Que foi se incluir isso na formação ajudaria. Não ajuda. Não ajuda. Porque a primeira vez que eu cheguei em uma sala de aula, eu tive vontade de sair correndo e não voltar, nunca mais. Porque, a primeira pergunta que a menina me fez, eu falei, eu quero afundar nesse chão. Então, é... a pessoa vai estudar isso tudo aí, vai chegar, vai pegar um aluno de inclusão e ela não vai nem saber o que fazer com esse sujeito. Talvez, isso me ocorreu agora, falte isso aqui ó [referindo-se ao momento da Conversação], pelo menos a cada fim de bimestre, falte isso aqui. A gente, os professores de apoio, a direção da escola, a supervisão, pra gente entrar num consenso, o que que nós vamos fazer pra esse menino progredir. 
A professora de Biologia acrescenta:

E de repente fechar, conseguir fechar em cima da fala de todo mundo, que são daquela turma, conseguir fechar o que realmente é uma progressão. A gente deveria usar o conselho de classe pra isso ao invés de ficar naquela falação que não rende.

A partir desse momento, quando tocam no desejo de ensinar, imaginariamente impossibilitado em função de uma deficiência "do" sujeito, alguns professores, dentre eles a professora de História, apontam um giro na Conversação e passam a relatar ações bemsucedidas com alunos da Educação Especial em sua turma, apresentando resultados mesmo que mínimos. Perguntada sobre ser possível os olhos brilharem por estes pequenos sucessos, responde:

Sim, é possível. Eu não espero que o meu aluno de inclusão aprenda da mesma forma, mas eu queria assim, sair da sala e falar, hoje eu ensinei alguma coisa pra ela. Né? (Profa. de História)

Apesar de um único encontro de Conversação diagnóstica, foi possível verificar nos fragmentos apresentados, a partir dos giros discursivos, a ocorrência de um instante de olhar, tempo para compreender e momento de concluir.

Aquele grupo de professores ainda não havia se reunido, incluindo na reunião as professoras de apoio, para tratarem das (im)possibilidades no ensino e aprendizagem dos conteúdos de suas áreas específicas em relação aos alunos da Educação Especial. A oferta da palavra, permitindo-lhes um lugar de escuta, possibilitou minimamente transpor o que vem de imediato como impeditivo - a queixa em relação à formação, à avaliação - e aparecer algo do desejo de ensinar, bem como da relação que estabelecem com o que vem marcado pelo laudo, anunciando um atravessamento naquilo que move o professor - "o brilho nos olhos".

A experiência da troca, sem a promessa de respostas prontas, permitida aos professores pelo simples convite à fala, oportunizou naquele momento que interrogassem o impossível, incluir pequenos possíveis, anunciar o trabalho coletivo como forma de diluir os impasses e somar as invenções.

Aparecem nesses fragmentos apresentados, nos dois grupos, questões de cada um que, em conjunto, vão de encontro com o previsto nas políticas de Educação Especial que orientam cada uma das redes de ensino. Questões que compõem os impasses para a efetivação do trabalho colaborativo, as quais, a partir do convite a falar, se esclarecem para o sujeito. Não se quer aqui defender a Conversação como solução para os problemas relacionados ao trabalho colaborativo na Educação Especial na escola comum. Mas, destacar o que foi possível aparecer a partir da aposta na Conversação e que talvez mereça receber um espaço nas pautas direcionadas ao coletivo, constituído de sujeitos de desejo, os quais podem lidar com a angústia - pela recusa ou pela invenção. 


\section{Algumas considerações}

Certamente são vários aspectos das singularidades envolvidos no sintoma do coletivo, os quais não são apreendidos no movimento da Conversação. Entretanto, a circulação da palavra permite que os sujeitos sejam tocados pelos significantes que surgem, de modo a produzirem um saber que, socializado naquele coletivo, culmina na produção de um saber do grupo, permitindo aos participantes o questionamento de identificações alienantes, que, silenciando o real com um ideal, não permitem a conexão do desejo docente com a perspectiva da inclusão.

Concordamos com Lima et al (2015) quando afirmam que:

Uma das possibilidades de se trabalhar com uma orientação psicanalítica nas instituições escolares é, pois, ofertando espaços de fala aos sujeitos, sejam eles alunos, professores ou pais, para que, no deslizar dos significantes, se abram novas perspectivas de interpretação de uma situação, desfazendo identificações geradoras de impotência, e produzindo novas saídas. (p. 1105)

Acreditamos que a oferta de espaços de fala, por meio das Conversações, nos dois grupos apresentados aqui, permitiu localizar pontos nodais que inviabilizam a relação dos professores com a proposta de Educação Especial na perspectiva da educação inclusiva. Destacou-se que a inclusão carrega vestígios do impossível da educação, bem como a relação com o desejo de conviver diariamente com alunos considerados deficientes ou diferentes. $\mathrm{O}$ que certamente interfere na efetivação do trabalho colaborativo, essencial à concretização das políticas previstas nas duas redes de ensino presentes nesta pesquisa-intervenção.

A partir das conclusões encaminhadas pelos grupos, propõe-se pensar o trabalho colaborativo para além da parceria objetiva entre professores de AEE, professores de apoio e de sala regular; ou seja, incluindo a dimensão da subjetividade dos sujeitos professores para a contínua produção de saber, no coletivo, diante da diversidade que constitui o universo escolar. Este trabalho aposta no efeito mobilizador, que abra alguma possibilidade nova, perspectivas inéditas, fonte de laço com o desejo de ensinar a todos e a cada um.

\section{Notas}

1. Resolução da Câmara de Educação Básica do Conselho Nacional de Educação que institui Diretrizes Nacionais para a Educação Especial na Educação Básica.

2. http://www2.educacao.mg.gov.br/component/gmg/page/16998-educacao-especial-na-perspectiva-da-educacaoinclusiva. Acesso em 03-02-2020.

3. O DSM-5, oficialmente publicado em 18 de maio de 2013, é a mais nova edição do Manual Diagnóstico e Estatístico de Transtornos Mentais da Associação Psiquiátrica Americana.

4. PORTARIA SMED $\mathrm{N}^{\circ}$ 112/2009 (http://portal6.pbh.gov.br/dom/iniciaEdicao.do?method=DetalheArtigo\&pk= 1000525) 
Centro interdisciplinar de estudos sobre a criança. Criado em 24 de julho de 1996 por Jacques-Alain Miller, na França, trata-se de uma instância internacional, onde a questão em jogo é abordar, de forma interdisciplinar, com os profissionais concernidos, as dificuldades encontradas pelas crianças e adolescentes no laço social. https://www.clin-a.com.br/cien

6. Agência financiadora: FUNDEP - Fundação de desenvolvimento da pesquisa.

7. Em 2019, a editora Autêntica lançou uma coleção de obras incompletas de Sigmund Freud, traduzida direta do alemão com o objetivo de estabelecer uma nova maneira de lidar com os seus escritos e convidando o leitor a questionar o caráter "completas" que o adjetivo traz. Nesta tradução o termo escolhido foi O Infamiliar.

\section{Referências}

ANJOS, Hildete P.; ANDRADE, Emmanuele P.; PEREIRA, Mirian Rosa. A inclusão escolar do ponto de vista dos professores: o processo de constituição de um discurso. Revista Brasileira de Educação, v. 14, n.40, p. 116-129, jan./abr. 2009.

BASTOS, Marise B.; KUPFER, Maria Cristina M. A escuta de professores no trabalho de inclusão escolar de crianças psicóticas e autistas. Estilos da clínica, v. 15, n. 1, p. 116-125, 2010.

BELO HORIZONTE. Conselho Municipal de Educação. Parecer n. 060/04. Diretrizes para a Educação Inclusiva de Pessoas com Deficiência e Condutas Típicas. Disponível em: https://prefeitura.pbh.gov.br/educacao/conselho/pareceres.

Secretaria Municipal de Educação. Portaria SMED n. 112/2009. Fixa normas para organização e funcionamento do Atendimento Educacional Especializado - AEE na Rede Municipal de Educação de Belo Horizonte - RME/BH. Disponível em: http://portal6.pbh.gov.br/dom/iniciaEdicao.do?method= DetalheArtigo \&pk=1000525.

Diário Oficial do Município. Lei n. 10.917, de 14 de março de 2016. Aprova o Plano Municipal de Educação de Belo Horizonte e dá outras providências. Disponível em: https://prefeitura.pbh.gov.br/sites/ default/files/estrutura-de-governo/educacao/Plano\%20Municipal\%20de\%20Educa\%C3\%A7\%C3\%A3o $\% 20(2)$.pdf.

BOAVENTURA JÚNIOR, Márcio. “SOBROU O APOIO!” Desencontro na construção da profissionalidade docente das professoras de apoio. 2019. Tese (Doutorado em Educação) - Faculdade de Educação, Universidade Federal de Minas Gerais, 2019.

BORGES, Adriana Araújo P.; CAMPOS, Regina Helena de F. A Escolarização de Alunos com Deficiência em Minas Gerais: das Classes Especiais à Educação Inclusiva1. Revista Brasileira Educação Especial, Bauru, v. 24, n. spe, p. 69-84, 2018. Disponível em: http://www.scielo.br/scielo.php?script=sci_arttext\&pid= S1413-65382018000500069 \&lng=en\&nrm=iso.

BRASIL. Congresso Nacional. Constituição da República Federativa do Brasil. Brasília: Senado Federal, Centro Gráfico, 1988.

BRASIL. Ministério da Educação. Secretaria de Educação Especial. Política Nacional de Educação Especial na Perspectiva da Educação Inclusiva. Brasília: MEC/SEESP, 2008.

BRASIL. Decreto no 7.611, de 17 de novembro de 2011. Dispõe sobre a Educação Especial, o Atendimento Educacional especializado e dá outras providências. 2011a. Disponível em: http://www.planalto.gov.br/ ccivil_03/_ato2011-2014/2011/decreto/d7611.htm. Acesso em: 27, junho, 2018.

CAMPOS, Regina Helena F. Helena Antipoff (1892-1974) e a perspectiva sociocultural em psicologia e educação. Tese (Concurso para Professor Titular) - Faculdade de Educação, Universidade Federal de Minas Gerais, Belo Horizonte, 2010.

CAMPOS, Regina Helena F.; LOURENÇO, Érika; ANTONINI, Isabel G. Introdução - Helena Antipoff e a psicologia no Brasil. In: CAMPOS, Regina Helena F. (Org.). Helena Antipoff: textos escolhidos.; São 
Paulo: Casa do Psicólogo Livraria e Editora Ltda, Brasília, DF: Conselho Federal de Psicologia, 2002. p. 12-36.

CAMPOS, Sofia Margarida G.; MARTINS, Rosa Maria L. Educação Especial: aspectos históricos e evolução conceptual. Revista do ISPV, Viseu, n. 34, p. 223-331, abr. 2008. Disponível em: http://www.ipv.pt/millenium/Millenium34/17.pdf.

CAPANEMA, Carla A.; VORCARO, Angela Maria R. A condição do ser falante no nó borromeano. Estilos da Clínica, São Paulo, v. 22, n. 2, p. 388-405, mai-ago, 2017. Disponível em: http://pepsic.bvsalud.org/scielo.php?script=sci_arttext\&pid=S1415-71282017000200011.

CHRISTO, Sandy V.; MENDES, Geovana M. L. Ensino colaborativo/coensino/bidocência para a educação inclusiva: as apostas para a produção científica. Instrumento: Revista de estudo e pesquisa em educação. Juiz de Fora, v. 21, n. 1, p. 33-44, jan.-jun. 2018.

DAMIANI, Magda Floriana. Entendendo o Trabalho Colaborativo em educação e revelando seus benefícios. Educ. rev., Curitiba, n. 31, p. 213-230, 2008. Disponível em: http://www.scielo.br/scielo.php?script=sci_ arttext\&pid=S0104-4060200800010001 3\& lng =en\&nrm=iso.

DINIZ, Débora. O que é deficiência. São Paulo: Brasiliense, 2007. (digitalizada).

FREUD, Sigmund. Psicologia de grupo e a análise do ego. In: Obras Psicológicas Completas de Sigmund Freud: Edição Standart Brasileira, vol. XVIII, Rio de Janeiro: Imago, 1976 [1921], p. 89-179.

O infamiliar. Ernani Chaves (Trad. e notas) e Pedro Heliodoro Tavares (Trad.). In: . $\mathrm{O}$ infamiliar e outros escritos. Obras incompletas de Sigmund Freud. Belo Horizonte: Autêntica, v. 8, 2019, p. 26-125.

GARDOU, Charles. A Sociedade Inclusiva: falemos dela! Não há vida minúscula. Belo Horizonte: Fino Traço/Editora UFMG, 2018.

HARGREAVES, A. Os professores em Tempos de Mudança. Amadora: Editora McgrawHill de Portugal, 1998.

KASSAR, Mônica C. M.; REBELO, Andressa S. O especial na educação, o atendimento especializado e a Educação Especial. In: VI Seminário Nacional de Pesquisa em Educação Especial, 2011, Nova Almeida, E.S. Prática pedagógica na Educação Especial: multiplicidade do atendimento educacional especializado. Porto Alegre: FCAA, v. 1. p. 1-17, 2011.

LACAN, Jacques. O Seminário: Livro 20, Mais, ainda. Rio de Janeiro: Jorge Zahar Editor, 1993 [1972-1973]. O tempo lógico e a asserção de certeza antecipada. In: 1998, p. 197-213.

LIMA, Nádia 1.; ARAÚJO, Ronaldo S.; SOUZA, Eduardo Pio; DIAS, Allana Fernanda G; BARBOSA, Carolina Albuquerque; ALVES, Raquel G. S.; NIHARI, Karina Maciel;

MARCHI, Nayara S. B. Psicanálise e Educação: um tratamento possível para as queixas escolares. Educação \& Realidade, v. 40, n. 4, p. 1103-1125, 2015.

LIMA, Nádia L.; KELLES, Natália Fernandes. Adolescentes no ciberespaço: uma reflexão psicanalítica. Tempo Psicanalítico, Rio de Janeiro, v. 49, n. 2, p. 202-233, 2017. Disponível em: http://pepsic.bvsalud.org/pdf/tpsi/v49n2/v49n2a10.pdf.

MARIÁS, Kátia de Oliveira; SANTIAGO, Ana Lydia. A educação profissionalizante de jovens em conflito com a lei: interferências do despertar da puberdade na tarefa de inserção no mundo do trabalho. 1. ed. Latvia: Novas Edições Acadêmicas, 2015.

MESQUITA, Raquel C. Inclusão na impossibilidade da educação: uma proposta de intervenção psicanalítica Tese (Doutorado em Educação). Faculdade de Educação, Universidade Federal de Minas Gerais, 2017.

MINAS GERAIS. Secretaria de Estado de Educação de Minas Gerais. Subsecretaria de Desenvolvimento da Educação Básica. Guia de Orientação da Educação Especial na rede estadual de ensino de Minas 
Gerais. Versão 3. 2014 file:///C:/Users/Lib\%C3\%A9ria/Downloads/Guia\%20da\%20Educa\%C3\%A7\%C3 $\%$ A3o\%20Especial\%20MG\%20vers\%C3\%A3o3\%20(3).pdf.

MINAS GERAIS. Secretaria de Estado de Educação. Resolução SEE No 4.256/2020. Diretrizes para normatização e organização da Educação Especial na rede estadual de Ensino de Minas Gerais. Disponível em: http://www2 .educacao.mg.gov.br/images/documentos/4256-20-r\%20-\%20Public.10-01-20.pdf.pdf

MINISTÉRIO DA EDUCAÇÃO. Conselho Nacional de Educação. Câmara de Educação Básica. Resolução n. 4, de 2 de outubro de 2009. Institui Diretrizes Operacionais para o Atendimento Educacional Especializado na Educação Básica, modalidade Educação Especial.

MIRANDA, Margarete P. Sobre a "criança-problema" e o mal-estar do professor. Dissertação (Mestrado em Educação). Universidade Federal de Minas Gerais, BH, MG: 2006.

O mal-estar do professor em face da criança considerada problema: um estudo de Psicanálise aplicada à educação. Tese (Doutorado em Educação). Faculdade de Educação, Universidade Federal de Minas Gerais, 2010.

MRECH, Leny M. Psicanálise e Educação: novos operadores de leitura. SP: Pioneira Thomson Learning, 2003.

NEVES, Libéria R. Teatro-Conversação na escola: o uso do Teatro na Conversação como mediados dos conflitos na educação. Tese (Doutorado em Educação). Faculdade de Educação, Universidade Federal de Minas Gerais, 2014.

PALHARES, Odana; BASTOS, Marise B. Duas notas sobre a formação de professores na perspectiva psicanalítica. Estilos da clínica, São Paulo, v. 22, n. 2, p. 246-267, maio/ago 2017. Disponível em: http://pepsic.bvsalud.org/pdf/estic/v22n2/ a03v22n2.pdf.

PLAISANCE, Eric. O especial na educação: significados e usos. Educação e realidade, Porto Alegre, v. 44, n. 1, p. 1-17, 2019.

ROCHA, Marisa L; AGUAR, Kátia F. Pesquisa-intervenção e a produção de novas análises. Revista Psicologia: Ciência e Profissão. Brasília, v. 23, n. 4, p. 64-73, 2003. Disponível em: http://www.scielo.br/scielo.php?pid=S1414-98932003000400010 \&script=sci_arttext.

SANCHES, I.; TEODORO, A. Da integração à inclusão escolar: cruzando perspectivas e conceitos. Revista Lusófona de Educação, Lisboa, v. 8, n. 8, p. 63- 83, jul. 2006. Disponível em: file:///C:/Users/liber/Downloads/691-Texto\%20do\%20artigo-2485-1-10-20090721.pdf.

SANTIAGO, Ana Lydia B. O mal-estar na educação e a Conversação como metodologia de pesquisaintervenção em Psicanálise e educação. In: Pesquisa-intervenção na infância e juventude. CASTRO, Lúcia R. e BESSET, Vera Lúcia (orgs). Rio de Janeiro: Trarepa/ FAPERJ, 2008. p. 113-131. Disponível em: http://www.brunabenvegnu.com/pesquisa-intervecao.pdf.

SANTIAGO, Ana Lydia B; MIRANDA, Margarete P; VASCONVELOS, Renata N. Pesquisa em Psicanálise e educação: a Conversação como metodologia de pesquisa. In: VI Colóquio do LEPSI. Psicanálise, Educação e Transmissão, 6., 2006, São Paulo. Disponível em: http://www.proceedings.scielo.br/scielo.php?pid=MSC00000000320 06000100060\&script=sci_arttext.

SANTIAGO, Ana Lydia; ASSIS, Raquel M. de. O que esse menino tem? sobre alunos que não aprendem e a intervenção da psicanálise na escola. Belo Horizonte: Editora Relicário 2018, p. 9-16.

SANTOS, Jácia M. Soares dos. A transferência no processo pedagógico: quando fenômenos subjetivos interferem na relação de ensino aprendizagem. Dissertação (Mestrado em Educação), Faculdade de Educação, Universidade Federal de Minas Gerais, BH, MG: 2009.

SILVA, Kelly Cristina Brandão. Educação Inclusiva: para todos ou para cada um? Alguns paradoxos (in)convenientes. Tese (Doutorado em Educação). Faculdade de Educação, Universidade de São Paulo, 2014.

TEIXEIRA, Antônio (Org.). Metodologia em ato. BH: Scriptum Livros, 2010. p. 25-37. 
UNESCO. Declaração de Salamanca: Sobre Princípios, Políticas e Práticas na Área das Necessidades Educativas Especiais, 1994.

VASCONVELOS, Renata N. Violência escolar: uma das manifestações contemporâneas do fracasso escolar. Tese (Doutorado em Educação). Faculdade de Educação, Universidade Federal de Minas Gerais, 2010.

VILARONGA, Carla A. R; MENDES, Enicéia G. Ensino colaborativo para o apoio à inclusão escolar: práticas colaborativas entre os professores. Rev. bras. Estud. pedagog. (online), Brasília, v. 95, n. 239, p. 139-151, jan./abr. 2014. Disponível em: http://www.scielo.br/pdf/rbeped/v95n239/a08v95n239.pdf.

\section{Correspondência}

Libéria Rodrigues Neves: Doutora em educação pela Universidade Federal de Minas Gerais (UFMG), onde atua como professora da graduação e pós-graduação (PROMESTRE). É integrante da Rede Internacional de Pesquisa em Psicanálise, Educação e Política (RIPPEP) e do Grupo de Trabalho de Psicanálise e Educação da Anpepp. ORCID: 0000-0001-7818-4434.

E-mail: liberianeves@gmail.com

Mônica Maria Farid Rahme: Doutora em educação pela Universidade de São Paulo. Atua no ensino, pesquisa e extensão na Faculdade de Educação da UFMG. É integrante da Rede Internacional de Pesquisa em Psicanálise, Educação e Política (RIPPEP), do Laboratório de Estudos e Pesquisas Psicanalíticas e Educacionais (LEPSIMinas) e do Grupo de Trabalho de Psicanálise e Educação da Anpepp. ORCID: 0000-0003-2123-2989.

E-mail: monicarahme@ufmg.br

Texto publicado em Currículo sem Fronteiras com autorização das autoras. 